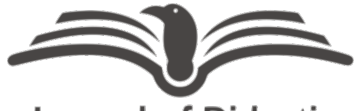

Journal of Didactic

Mathematics

\title{
Analisis kepercayaan diri mahasiswa pendidikan matematika dalam pembelajaran daring di era pandemi covid-19
}

\section{Fitriani*}

Universitas Muhammadiyah Tapanuli Selatan, Padangsidimpuan, Sumatera Utara, Indonesia, 22716

\section{Benny Sofyan Samosir}

Universitas Muhammadiyah Tapanuli Selatan, Padangsidimpuan, Sumatera Utara, Indonesia, 22716

\section{Winmery Lasma Habeahan}

AMIK D3 Medicom, Medan, Sumatera Utara, Indonesia, 20153

*Corresponding Author. fitriani@um-tapsel.ac.id

\begin{abstract}
Self-confidence is one of the affective aspects that must be considered and developed, especially in building student readiness in undergoing online learning in the current pandemic era. This study aims to analyze the confidence of mathematics education students in online learning in the era of the covid-19 pandemic. This research use descriptive qualitative approach. The subjects of this study were first semester students who took the Differential Calculus course in the Mathematics Education study program at the Universitas Muhammadiyah Tapanuli Selatan for the 2021/2022 academic year. The instrument used in this research is a questionnaire. The data obtained in this study were analyzed descriptively. Based on the results of the study, it shows that the indicators of student self-confidence in online learning in the era of the covid-19 pandemic have not fully achieved, but most of the indicators have mostly achieved self-confidence, namely the first indicator of believing in selfability, most of them have achieved self-confidence. Students also have not fully met the second indicator, namely being able to act independently in making decisions. In the third indicator having a positive self-concept, most students have achieved this indicator. In the fourth indicator, namely daring to express opinions, almost some students have the courage to express opinions. To further increase student confidence, it is necessary to provide innovation in the implementation of online learning.
\end{abstract}

Historis Artikel:

Diterima: 17 Desember

2021

Direvisi: I Januari 2022

Disetujui: 14 Januari 2022

\section{Keywords:}

Analysis; self-confidence; online learning

Sitasi: Fitriani, F., Samosir, B. S., \& Habeahan, W. L. (2021). Analisis kepercayan diri mahasiswa pendidikan matematika dalam pembelajaran daring di era pandemi covid-19. Journal of Didactic Mathematics, 2(3), 142-148. Doi: $10.34007 / j \mathrm{dm} . v 2 \mathrm{i} 3.1040$

\section{PENDAHULUAN}

Pendidikan sangat berperan penting dalam perubahan tingkah laku seseorang baik secara fisik dan psikis. Pendidikan merupakan pondasi yang menentukan pola tingkah laku seseorang, baik melalui pendidikan formal dan informal. Hal ini sejalan dengan pendapat Syafinuddin al Mandari (Vandini, 2015), pendidikan dilaksanakan bukan hanya sekedar untuk mengejar nilai-nilai, melainkan memberikan pengarahan kepada setiap orang agar dapat bertindak dan bersikap benar sesuai dengan kaidah-kaidah dan spirit keilmuan yang dipelajari. Untuk mencapai hasil yang baik maka salah satunya tidak lepas dari diri individunya baik faktor eksternal maupun internalnya. Salah satu faktor yang sangat mempengaruhi yaitu faktor internal berupa kepercayaan diri (self-confidence).

Muawwanah, Ma'rufi dan Nurdin (2020) menyatakan kepercayaan diri (self-confidence) merupakan sikap percaya seseorang dengan kemampuan dirinya. Dewi, Puspadewi dan Wibawa (2020) menyatakan kepercayaan diri siswa merupakan suatu keyakinan terhadap dirinya untuk mengembangkan potensi yang ada di dalam diri untuk mencapai sesuatu yang bermanfaat untuk 
Analisis kepercayaan diri mahasiswa pendidikan matematika dalam...

dirinya sendiri dan orang disekitarnya. Menurut Lauster (Khair \& Soleh, 2021) kepercayaan diri merupakan suatu sikap atau keyakinan atas kemampuan diri sendiri sehingga dalam tindakantindakannya tidak terlalu cemas, merasa bebas untuk melakukan hal-hal yang sesuai keinginan dan tanggung jawab atas perbuatannya, sopan dalam berinteraksi dengan orang lain, memiliki dorongan prestasi serta dapat mengenal kelebihan dan kekurangan diri sendiri. Eggen \& Kauchak (Susanto, Rusdi \& Susanta, 2020) menyebutkan bahwa kepercayaan diri merupakan pernyataan yang menggambarkan sebuah kepercayaan, sebuah ide kognitif diterima jika benar tanpa perlu mempertimbangkan hal lain yang mendukung.

Berdasarkan beberapa pernyataan di atas disimpulkan bahwa kepercayaan diri adalah keyakinan seseorang akan kemampuan dirinya untuk mencapai kesuksesan baik sukses secara akademik, sosial, dan masyarakat serta mampu mengenal kelebihan dan kekurangan yang ada pada dirinya. Hal ini didukung oleh pendapat Isna (2011) bahwa "kepercayaan diri merupakan sebuah kekuatan yang luar biasa laksana reaktor yang membangkitkan segala energi yang ada pada diri seseorang untuk mencapai sukses. Begitu juga menurut Fardani, Surya dan Mulyono (2021) bahwa kepercayaan diri (self-confidence) adalah perasaan yakin akan kemampuan sendiri yang mencakup penilaian dan penerimaan yang baik terhadap dirinya secara utuh, bertindak sesuai dengan apa yang diharapkan oleh orang lain sehingga individu dapat diterima oleh orang lain maupun lingkungannya. Penerimaan ini meliputi penerimaan secara fisik dan psikis.

Kepercayaan diri (self-confidence) sangat mempengaruhi keberhasilan seseorang, karena kepercayaan diri setiap orang berbeda dan tidak terikat satu sama lain. Kepercayaan diri juga merupakan salah satu watak/jati diri yang sudah pasti ada dalam diri setiap manusia. Hal ini diperkuat Loekmono (Hartono \& Saputro, 2018) mengemukakan bahwa kepercayaan diri tidak terbentuk dengan sendirinya melainkan berkaitan dengan kepribadian seseorang. Begitu juga menurut Komara (Amri, 2018) bahwa semakin tinggi kepercayaan diri dan prestasi belajar maka perencanaan karir semakin tinggi dan sebaliknya apabila kepercayaan diri dan prestasi belajar rendah maka perencanaan karir akan semakin rendah. Fardani, Surya dan Mulyono (2021) orang yang memiliki kepercayaan diri mempunyai ciri-ciri: toleransi, tidak memerlukan dukungan orang lain dalam setiap mengambil keputusan atau mengerjakan tugas, selalu bersikap optimis dan dinamis, serta memiliki dorongan prestasi yang kuat.

Kepercayaan diri perlu dikembangkan dan diperhatikan terutama di dunia pendidikan baik untuk siswa maupun mahasiswa agar tujuan dari pendidikan maupun pembelajaran tercapai sesuai yang diharapkan. Namun yang menjadi kendala pada saat ini yaitu situasi yang mewajibkan semua elemen masih melakukan aktivitas jarak jauh atau jaga jarak dikarenakan masih mewabahnya covid19 baik secara nasional maupun internasional. Elemen yang sangat berdampak dari wabah covid19 ini adalah dunia pendidikan, dimana sistem pembelajaran beralih menjadi dalam jaringan (daring) maupun online. Pembelajaran daring tergolong sebagai proses pembelajaran baru bagi siswa maupun mahasiswa yang dilakukan untuk menyiasati kegiatan pembelajaran dari rumah selama masa pandemi covid-19. Malyana (2020) menyatakan pembelajaran daring adalah metode belajar yang menggunakan model interaktif berbasis internet dan learning manajemen system (LMS). Seperti menggunakan aplikasi online zoom, google meet, google drive, google classroom dan lain sebagainya. Badriyah, Akhwani, Nafiah dan Djazilan (2021) menjelaskan pembelajaran daring merupakan pembelajaran yang dilakukan secara jarak jauh dengan memanfaatkan teknologi digital sebagai alat komunikasi dan media penyalur materi pelajaran. Menurut Bilfaqih (Setiawan dkk., 2021) dengan adanya pembelajaran daring yang memanfaatkan multimedia akan membantu peningkatan mutu pendidikan dan pelatihan yang efektif dalam metode pembelajaran, dengan belajar secara daring akan terjadi peningkatan jangkauan pendidikan dan pelatiahan, serta dengan pemanfaatan sumber daya ini mampu menekan biaya pendidikan dan pelatihan.

Mengingat pembelajaran daring yang digunakan saat ini maka keberhasilan mahasiswa berhubungan dengan gaya belajar mahasiswa di rumah. Maka secara tidak langsung erat kaitannya dengan kepercayaan diri mahasiswa khususnya dalam pembelajaran matematika. Sebab dalam pembelajaran matematika sangat dibutuhkan tanggung jawab, kerja keras dan kepercayaan diri 
mahasiswa khususnya dalam menyelesaikan masalah-masalah yang berkaitan dengan materi yang akan diberikan oleh dosen. Adapun indikator kepercayaan diri yang dimaksud dalam penelitian ini nantinya merujuk pada indikator kepercayaan diri yang dikembangkan oleh Pangestu dan Sutirna (2021) yaitu percaya kepada kemampuan diri sendiri, bertindak mandiri dalam mengambil keutusan, memiliki konsep diri yang positif dan berani mengemukakan pendapat.

Tujuan utama dari pembelajaran matematika adalah untuk menumbuhkan rasa percaya diri siswa akan kemampuan yang dimilikinya, seorang pendidik dapat membantu menumbuhkan kepercayaan diri siswa melalui pemberian tugas atau permasalahan serta memberikan peluang bagi siswa untuk belajar, bereksplorasi dan berusaha menemukan serta mengaplikasikan benda ataupun alat yang dapat membantu mereka dalam menemukan dan memahami konsep matematika. Melalui proses ini siswa akan terlatih dalam menyelesaikan tugas ataupun permasalahan mereka secara mandiri sehingga menumbuhkan kemandirian dan kepercayaan terhadap kemampuan yang dimilikinya (Chodijah, 2010). Berdasarkan hal ini perlu dilakukan tinjauan kepercayaan diri mahasiswa dalam pembelajaran matematika khususnya pada proses pembelajaran daring. Dari latar belakang di atas yang menjadi tujuan penelitian ini adalah untuk mengalisis kepercayaan diri mahasiswa pendidikan matematika menggunakan model pembelajaran daring di era pandemi covid-19.

\section{METODE}

Jenis Penelitian ini menggunakan pendekatan deskriptif kualitatif. Moleong (2017) mendefenisikan bahwa penelitian kualitatif adalah penelitian yang bermaksud untuk memahami fenomena tentang apa yang dialami oleh subjek penelitian, misalnya perilaku, persepsi, motivasi, tindakan dan lain-lain secara holistik dan dengan cara deskripsi dalam bentuk kata-kata dan bahasa, pada suatu konteks khusus yang alamiah dan dengan memanfaatkan berbagai metode alamiah.

Subyek penelitian ini adalah seluruh mahasiswa semester I yang mengambil matakuliah Kalkulus Diferensial pada program studi Pendidikan Matematika Universitas Muhammadiyah Tapanuli Selatan Tahun Ajaran 2021/2022 yaitu sebanyak 15 orang.

Pengumpulan data dilakukan melalui pemberian angket dengan empat indikator kepercayaan diri yang berisi 20 pernyataan dengan empat pilihan jawaban yaitu sangat sesuai, sesuai, tidak sesuai dan sangat tidak sesuai. Adapun indikator dan contoh bentuk pernyataan yang tersaji di dalam angket dapat dilihat pada Tabel 1 berikut.

Tabel 1. Indikator kepercayaan diri dan contoh bentuk pernyataannya

\begin{tabular}{crl}
\hline \multicolumn{1}{c}{ Indikator } & \multicolumn{1}{c}{ Bentuk Pernyataan } \\
\hline Percaya kepada kemampuan diri sendiri & 1. $\begin{array}{l}\text { Kemampuan yang saya miliki tidak sebaik } \\
\text { kemampuan teman-teman lainnya }\end{array}$ \\
& $\begin{array}{l}\text { 2. } \begin{array}{l}\text { Saya sering menyamakan jawaban tugas } \\
\text { dengan teman }\end{array} \\
\end{array}$
\end{tabular}

\begin{tabular}{llll}
\hline $\begin{array}{l}\text { Bertindak mandiri dalam mengambil } \\
\text { kepustusan }\end{array}$ & $\begin{array}{l}\text { Saya bisa mengambil keputusan tanpa } \\
\text { meminta bantuan dan pertimbangan dari } \\
\text { teman }\end{array}$
\end{tabular}

2. Saya selalu meminta pendapat teman ketika akan melakukan sesuatu hal

Memiliki konsep diri yang positif
1. Saya mampu menjelaskan materi pelajaran kepada teman yang belum paham

2. Saya memilih diam saja ketika dosen mengajukan pertanyaan di zoom/google meet/Google Classroom walaupun Saya tahu jawabannya 
Analisis kepercayaan diri mahasiswa pendidikan matematika dalam...

\begin{tabular}{cl}
\hline \multicolumn{1}{c}{ Indikator } & \multicolumn{1}{c}{ Bentuk Pernyataan } \\
\hline Berani Mengemukakan pendapat & 1. $\begin{array}{l}\text { Saya masih takut, malu dan ragu-ragu } \\
\text { untuk mengemukakan pendapat ketika } \\
\text { pembelajaran matematika berlangsung } \\
\text { secara daring }\end{array}$ \\
2. $\begin{array}{l}\text { Ketika Pembelajaran Berlangsung secara } \\
\text { daring, Saya berani bertanya tanpa tanpa } \\
\text { harus ditunjuk dosen apabila ada yang } \\
\text { belum saya mengerti }\end{array}$ \\
\hline
\end{tabular}

Angket yang digunakan menggunakan skala Likert dengan rentang nilai 4 sampai 1. Pengisian angket oleh mahasiswa menggunakan bantuan aplikasi google form. Analisis data yang digunakan ialah deskriptif yang bertujuan mendesripsikan kepercayaan diri mahasiswa dalam pembelajaran matematika melalui pembelajaran daring.

Untuk mendapatkan hasil persentase dari tiap item pernyataan digunakan rumus sebagai berikut: $p=\frac{f}{n} \times 100 \%$

(Pangestu \& Sutirna, 2021)

Keterangan:

p: Persentase jawaban

f: Frekuensi jawaban

n: Jumlah siswa

Untuk mengetahui kriteria terhadap hasil persentase yang telah diperoleh dapat dilihat pada Tabel 2 berikut.

Tabe1 2. Kriteria untuk hasil jawaban angket (Pangestu \& Sutirna, 2021)

$\begin{array}{cc}\text { Kriteria } & \text { Penafsiran } \\ 0 \% & \text { Tak seorang pun } \\ 05<\mathrm{p}<25 \% & \text { Sebagian kecil } \\ 25 \% \leq \mathrm{p} \leq 50 \% & \text { Hampir Sebagian } \\ \mathrm{p}=50 \% & \text { Sebagian } \\ 50 \% \leq \mathrm{p} \leq 75 \% & \text { Sebagian besar } \\ 75 \% \leq \mathrm{p} \leq 100 \% & \text { Hampir seluruhnya } \\ 100 \% & \text { Seluruhnya }\end{array}$

\section{HASIL DAN PEMBAHASAN}

Berdasarkan hasil angket kepercayaan diri mahasiswa yang diberikan kepada seluruh mahasiswa yang mengikuti mata kuliah Kalkulus diferensial yaitu sebanyak 15 orang, peneliti melakukan analisis terhadap hasil jawaban angket mahasiswa. Berikut pada Tabel 3 adalah data yang diperoleh setelah dilakukan perhitungan untuk mendapatkan jumlah persentase pada setiap indikator kepercayaan diri yang dimiliki oleh seluruh mahasiswa semester I yang mengambil matakuliah Kalkulus Diferensial pada program studi Pendidikan Matematika Universitas Muhammadiyah Tapanuli Selatan Tahun Ajaran 2021/2022.

Tabel 3. Jumlah Persentase Setiap Indikator Angket Kepercayaan Diri

\begin{tabular}{cc}
\hline Kriteria & Penafsiran \\
\hline Percaya kepada kemampuan diri sendiri & $50,2 \%$ \\
Bertindak mandiri dalam mengambil kepustusan & $46,4 \%$ \\
Memiliki konsep diri yang positif & $52,6 \%$ \\
Berani Mengemukakan pendapat & $48,2 \%$ \\
\hline
\end{tabular}


Berdasarkan Tabel 3 diperoleh bahwa pada indikator pertama yaitu percaya kepada kemampuan diri sendiri yaitu sebesar 50,2\%, artinya dapat dilihat pada Tabel 2 kriteria menunjukan bahwa "sebagian besar" mahasiswa telah memliliki kepercayaan diri terhadap kemampuan yang dimilikinya namun sebagian lainnya belum mencapai indikator tersebut karena terdapat sebagian mahasiswa yang baru mengerjakan tugas jika sudah diingatkan oleh dosen, mahasiswa juga tidak aktif ketika pembelajaran daring banyak mahasiswa yang enggan untuk maju/mempersentasekan mengerjakan soal zoom/google meet, hal itu menunjukan rendahnya kepercayan diri mahasiswa terhadap kemampuan yang dimilikinya. Kebiasaan yang lainnya yaitu mahasiswa sering menyamakan jawaban tugas dengan temannya, ini menunjukan bahwa mahasiswa belum memiliki rasa percaya diri terhadap kemampuannya. Ketidakpercayaan terhadap kemampuan diri mereka juga dipengaruhi pemahaman mahasiswa terhadap materikuliah yang diterimanya. Mengingat adanya keterbatasan dosen dalam memberikan penjelasan yang tidak dapat dilakukan seperti proses pembelajaran tatap muka. Fauzy dan Nurfauziah (2021) menyatakan bahwa dalam praktiknya pembelajaran daring tidak semaksimal pembelajaran dikelas, terutama pada pelajaran matematika.

Pada indikator kedua yaitu bertindak mandiri dalam mengambil keputusan, berdasarkan Tabel 3 diperoleh sebesar 46,4\% mahasiswa yang dapat mencapai indikator tersebut, berdasarkan kriteria artinya "hampir sebagian" dari jumlah mahasiswa memiliki sikap bertindak mandiri dalam mengambil keputusan namun sisanya masih belum mencapai indikator tersebut. Sebagian besar mahasiswa masih ragu jika menjawab latihan soal secara mandiri karena siswa tidak percaya diri jika harus memutuskan untuk mengerjakan soal sendiri tanpa bantuan orang lain, banyak mahasiswa yang cenderung takut salah akan jawabannya. Hal itu dapat dilihat sebagian besar mahasiswa terlambat mengirimkan tugas di google classroom, dimana waktu yang diberikan dalam pengiriman tugas secara daring cukup lama yaitu melebihi batas jam perkulihan yang seharusnya namun masih saja menyerahkan tugas terlambat dan harus diingatkan. Berdasarkan wawancara yang dilakukan secara acak, ditemukan fakta bahwa salah satu penyebabnya adalah kurangnya penguasaan dan pemahaman mahasiswa terhadap konsep yang dipelajari. Hal ini sejalan dengan pandangan Khair dan Soleh (2021) bahwa pada dasarnya setiap siswa mendapat kepercayaan dirinya ketika mereka memahami materi yang diberikan.

Pada indikator ketiga yaitu memiliki konsep diri yang positif diperoleh nilai sebesar 52,6\%, dapat dilihat dari kriteria pada Tabel 2 bahwa hal itu menunjukan "sebagian besar" mahasiswa telah memiliki konsep diri yang positif namun sebagian kecil dari keseluruhan mahasiswa belum memiliki konsep diri yang positif karena masih ada mahasiswa yang kurang bersemangat saat belajar matematika secara daring hal ini diketahui ketika dosen menanyakan di setiap akhir perkuliahan secara daring baik di google classroom dan google meet terkait pembelajaran secara daring atau dari rumah. Hal itu menunjukan bahwa mahasiswa masih ada yang belum memiliki kosep diri yang positif terutama dalam menyikapi situasi pandemi covid-19.

Menurut Yulia dan Putra (2020) kesulitan yang sering terjadi melalui konsep diri atau kemampuan diri ketika siswa belajar online matematika bagi peserta didik di rumah yaitu kurangnya atau belum adanya insiatif untuk belajar sendiri dan lebih cenderung menunggu instruksi ataupun arahan, dalam mempelajari materi matematika peserta didik cenderung hanya mempelajari apa yang disampaikan oleh pendidik saja tanpa ada inisiatif untuk mengembangkannya, belum bisa memonitor, mengatur, dan mengontrol belajar online dirumah, masih terkesan belajar yang seperlunya, dan peserta didik jarang melakukan evaluasi proses terhadap hasil belajarnya.

Pada indikator terakhir atau indikator keempat yaitu berani mengemukakan pendapat diperoleh hasil persentase sebesar 48,2\%, artinya "hampir sebagian" mahasiswa mencapai indikator tersebut namun sebagian mahasiswa lainnya masih takut, malu dan ragu-ragu untuk mengemukakan pendapat ketika pembelajaran matematika. Mahaiswa cenderung takut akan pendapatnya yang salah karena itu mahasiswa lebih memilih untuk tidak mengutarakan pendapatnya. Hal ini dibuktikan ketika pembelajaran secara zoom mahasiswa lebih banyak memilih diam ketika disuruh mempersentasekan hasil jawabannya dimana mahasiswa terkesan saling menunggu untuk tampil. Ketika dimintai oleh dosen baru berani mengutarakan pendapatnya, 
Analisis kepercayaan diri mahasiswa pendidikan matematika dalam...

namun dapat diperkirakan ini terjadi karena proses perkuliahan masih baru bagi mereka mengingat subjek penelitian ini adalah mahasiswa semester I yang masih perlu dibina dan dimotivasi.

Dari keseluruhan indikator diperoleh rata-rata persentasenya yaitu sebesar 49,4\%, ini menunjukan bahwa sebesar 49,4\% mahasiswa semester I yang mengambil matakuliah Kalkulus Diferensial pada program studi Pendidikan Matematika Universitas Muhammadiyah Tapanuli Selatan Tahun Ajaran 2021/2022 miliki kepercayaan diri yang baik dan 50,6\% mahasiswa masih belum memiliki kepercayaan diri yang baik dalam pembelajaran matematika melalui pembelajaran daring di era pandemic covid-19. Hal ini dapat disimpulkan sebagai salah satu keterbatasan dalam proses pembelajaran daring. Yulia dan Putra (2020) menyatakan bahwa pembelajaran matematika secara daring memiliki banyak kekurangan di antaranya yaitu, Kurangnya interaksi antara guru dan siswa. Kurangnya interaksi ini bisa memperlambat terbentuknya penilaian serta penalaran pada pelajaran matematika dalam proses belajar dan mengajar. Kecenderungan mengabaikan aspek akademik maupun aspek sosial. Proses belajar dan mengajarnya lebih ke arah pelatihan daripada kependidikan dan mayoritas siswa tidak memiliki motivasi belajar matematika (Yazdi et al., 2012).

\section{KESIMPULAN}

Berdasarkan dari hasil data diperoleh bahwa mahasiswa belum sepenuhnya mencapai pada indikator-indikator kepercayaan diri, namun sebagian indikator sudah sebagian besar tercapai. Adapun penjelasan dari keempat indikator yaitu indikator pertama berupa percaya kepada kemampuan diri. Sebagian besar sudah mencapai kepercayaan diri dan hanya sebagian kecil mahasiswa belum sepenuhnya memiliki kepercayaan kepada kemampuan dirinya sendiri hal itu dibuktikan dari data yang diperoleh bahwa hanya sebagian kecil mahasiswa yang memiliki kebiasaan menyamakan jawaban tugas dengan temannya. Mahasiswa juga belum sepenuhnya memenuhi indikator kedua yaitu dapat bertindak mandiri dalam mengambil keputusan karena mahasiswa masih ragu jika mengerjakan latihan soal secara mandiri. Pada indikator ketiga memiliki konsep diri yang positif sudah sebagian besar mahasiswa yang mencapai indikator ini dan hanya sebagian kecil mahasiswa yang masih kurang bersemangat dan malas belajar matematika secara daring. Pada indikator keempat yaitu berani mengemukakan pendapat, sudah hampir sebagian mahasiswa memiliki keberanian mengemukakan pendapat tetapi lebih sebagian lagi mahasiswa memiliki kepercayaan diri yang cukup rendah karena mahasiswa masih belum percaya diri untuk mengemukakan pendapat ketika kegiatan pembelajaran matematika berlangsung secara daring baik di google classroom maupun di zoom/google meet. Untuk pendidik sebaiknya dapat menggunakan teknik dan strategi mengajar yang lebih inovatif secara daring guna meningkatkan kepercayaan diri mahasiswa terutama dalam mengajarkan pelajaran matematika agar kepercayaan diri mahasiswa lebih meningkat, untuk universitas yaitu diharapkan dapat rutin dalam memberikan motivasi terhadap mahasiswa agar dapat menumbuhkan rasa percaya diri mahasiswa, dan juga untuk mahasiswa sebaiknya dapat menumbukan rasa percaya diri yang baik dalam pembelajaran matematika agar mahasiswa dapat lebih semangat dan aktif ketika pembelajaran matematika baik nantinya secara daring maupun luring.

\section{DAFTAR PUSTAKA}

Amri, S. (2018). Pengaruh kepercayaan diri (self confidence) berbasis ekstrakurikuler pramuka terhadap prestasi belajar matematika siswa SMA Negeri 6 Kota Bengkulu. Jurnal Pendidikan Matematika Raflesia, 3(2), 156-170. https://doi.org/10.33449/jpmr.v3i2.7520

Badriyah, I. R., Akhwani, A., Nafiah, N., \& Djazilan, M. S. (2021). Analisis model pembelajaran daring dan luring pada masa pandemi covid-19 di sekolah dasar. Jurnal Basicedu, 5(5), 36513659 https://doi.org/10.31004/basicedu.v5i5.1373

Chodijah, S. (2010). Pembelajaran berbasis dap untuk meningkatkan percaya diri siswa dalam belajar matematika: Penelitian tindakan kelas di SDI Ruhama Cirebon. (Skripsi) diakses di https://repository.uinjkt.ac.id/dspace/handle/123456789/1390 
Dewi, P. T. I. C., Puspadewi, K. R., \& Wibawa, K. A. (2020). Pengaruh kepercayaan diri terhadap hasil belajar matematika siswa kelas VIII SMP Negeri 5 Kuta Selatan. Prosiding Mahasaraswati Seminar Nasional Pendidikan Matematika 2020, Denpasar - Indonesia, 77-86. https://ejournal.unmas.ac.id/index.php/Prosemnaspmatematika/article/view/911

Fardani, Z., Surya, E., \& Mulyono, M. (2021). Analisis kepercayaan diri (self-confidence) siswa dalam pembelajaran matematika melalui model problem based learning. Paradikma: Jurnal Pendidikan Matematika, 14(1), 39-51. https://doi.org/10.24114/paradikma.v14i1.24809

Fauzy, A., \& Nurfauziah, P. (2021). Kesulitan pembelajaran daring matematika pada masa pandemi COVID-19 di SMP Muslimin Cililin. Jurnal Cendekia: Jurnal Pendidikan Matematika, 5(1), 551 561. https://doi.org/10.31004/cendekia.v5i1.514

Hartono, H., \& Saputro, M. (2018). Pembentukan Kepercayaan Diri Mahasiswa Pendidikan Matematika Melalui Penerapan Supercamp. Majamath: Jurnal Matematika dan Pendidikan Matematika, 1(1), 43-56. https://doi.org/10.36815/majamath.v1i1.60

Isna, N. (2011). Panduan menerapkan pendidikan karakter di sekolah. Yogyakarta: Laksana.

Khair, S. N., \& Soleh, H. (2021). Analisis dampak covid-19 terhadap kepercayaan diri siswa dalam pembelajaran matematika berbasis online. PENSA, 3(2), 311-321. https://doi.org/10.36088/pensa.v3i2.1365

Malyana, A. (2020). Pelaksanaan pembelajaran daring dan luring dengan metode bimbingan berkelanjutan pada guru sekolah dasar di Teluk Betung Utara Bandar Lampung. Pedagogia: Jurnal Ilmiah Pendidikan Dasar Indonesia, 2(1), 67-76. DOI: 10.52217/pedagogia.v2i1.640

Moleong, L. J. (2017). Metodologi penelitian kualitatif. Bandung: PT Remaja Rosdakarya.

Muawwanah, M., Ma'rufi, M., \& Nurdin, N. (2020). Korelasi antara kepercayaan diri dan kemandirian belajar terhadap hasil belajar matematika siswa sekolah dasar. Proximal: Jurnal Penelitian Matematika dan Pendidikan Matematika, 3(2), 1-15.

Pangestu, R. A., \& Sutirna, S. (2021). Analisis kepercayaan diri siswa terhadap pembelajaran matematika. Maju: Jumal Ilmiah Pendidikan Matematika, 8(1), 118-125.

Setiawan, A. P., Masruri, L., Trastianingrum, S. A. P., \& Purwandari, E. (2021). Efek metode pembelajaran daring (pembelajaran jarak jauh) akibat covid-19: Perspektif pelajar dan mahasiswa. Proyeksi: Jurnal Psikologi, 16(1), 83-91. http://dx.doi.org/10.30659/ip.16.1.83-91

Susanto, E., Rusdi, R., \& Susanta, A. (2020). Peningkatan kepercayaan diri mahasiswa dalam pembelajaran statistika dasar melalui problem based-learning. Jurnal THEOREMS (The Original Research of Mathematics), 4(2), 179-184. http://dx.doi.org/10.31949/th.v4i2.1683

Vandini, I. (2016). Peran kepercayaan diri terhadap prestasi belajar matematika siswa. Formatif: Jurnal Ilmiah Pendidikan MIP A, 5(3), 210-219. http://dx.doi.org/10.30998/formatif.v5i3.646

Yazdi, M. (2012). E-Learning sebagai media pembelajaran. Foristek: Forum Teknik Elektro dan Teknologi Informasi, 2(1), 143-152.

Yulia, I. B., \& Putra, A. (2020). Kesulitan siswa dalam pembelajaran matematika secara daring. Refleksi Pembelajaran Inovatif, 2(2), 327-335. https://doi.org/10.20885/rpi.vol2.iss2.art4 